\title{
La ciudad en la poesía de Efraín Huerta: un amor de amarga raíz
}

\author{
The city in the poetry of Efrain Huerta: \\ a love of bitter root
}

\author{
Fortino CORRAL Rodríguez \\ ORCID: 0000-0002-8933-3957 \\ Universidad de Sonora, México \\ fortino.corral@unison.mx
}

Resumen:

En el presente artículo se analiza la poesía urbana de Efraín Huerta con un enfoque semiótico. Se establece primeramente el contexto literario con que esta dialoga y enseguida se realiza el análisis intrínseco del corpus poético considerado. El contexto dialógico se describe tomando en cuenta que Efraín Huerta pertenece a la generación de 1914, que es la que prosigue inmediatamente a la del grupo Contemporáneos; en este punto se advierte que el rasgo distintivo de la generación de Huerta es su marcado interés por los asuntos sociales. El análisis de los textos tiene como objetivo explicar la manera en que se organiza y se produce la significación. Para ello se distinguen dos sistemas organizativos: uno, de tipo narrativo, basado en el esquema actancial, y otro sensorial-afectivo, que centra su atención en el devenir pasional del sujeto. El primero tiene su anclaje en la semiótica greimasiana de los años sesenta, mientras que el segundo se basa en las aportaciones de la semiótica tensiva, desarrollada en las últimas tres décadas por Jacques Fontanille y Claude Zilberberg, entre otros. Se recurre, además, a otras contribuciones teóricas como la semiótica cultural de Iuri Lotman, el modelo triádico de Peirce y algunos conceptos fundamentales del pensamiento de Gilles Deleuze. 
Palabras clave:

poesía urbana, poesía civil, Efraín Huerta, sujeto lírico, semiótica tensiva.

Abstract:

This article analyzes Efraín Huerta's urban poetry with a semiotic approach. First, the literary context with which it dialogues is established and then the intrinsic analysis of the poetic corpus considered is carried out. The dialogic context is described taking into account that Efraín Huerta belongs to the generation of 1914, which is the one that immediately follows that of the Contemporáneos group; at this point it is noted that the distinctive feature of Huerta's generation is their marked interest in social issues. The analysis of the texts aims to explain the way in which meaning is organized and produced. To this end, two organizational systems are distinguished: one, of a narrative type, based on the actancial model, and the other sensorial-affective, which focuses its attention on the passional becoming of the subject. The former is anchored in Greimas' sixties semiotics, while the latter is based on the contributions of tensional semiotics, developed in the last three decades by Jacques Fontanille and Claude Zilberberg, among others. It also draws on other theoretical contributions such as the cultural semiotics of Iuri Lotman, Peirce's triadic model and some fundamental concepts of Gilles Deleuze's thought.

Keywords:

urban poetry, civilian poetry, Efraín Huerta, lyrical subject, Tensive Semiotics.

DOI: https://doi.org/10.36798/critlit.v0i23.386

Recibido: 18 de marzo de 2021

Aceptado: 20 de mayo de 2021 


\section{Introducción}

El tema de la ciudad no es un asunto fortuito en la poesía de Efraín Huerta, sino un elemento constitutivo de su poética, la cual comporta una profunda vocación cívica. En este trabajo analizaremos la relación que la voz poética establece con la ciudad. Adoptaremos para ello una mirada semiótica, lo cual nos lleva a tomar el texto poético como enunciación, por lo que la ciudad referida en estos poemas es una construcción discursiva que el poeta lleva a cabo en diálogo polémico con los otros textos de la cultura. ${ }^{1}$ Es por ello que para este análisis resulta indispensable tomar nota del momento histórico en que se da la actividad productiva de Huerta y el lugar que ocupa su obra en el entramado generacional de la literatura mexicana. Desde luego, no se pretende aquí una explicación causal, sino solamente ratificar la premisa de que la literatura mantiene una relación dialógica con el resto de los discursos culturales. Nuestro trabajo no se posiciona en ese ángulo metodológico, sino que, a tono con la semiótica del discurso, se ocupa de analizar la manera en que se organiza el sentido ${ }^{2}$ en el interior del corpus textual considerado.

Comenzaremos, pues, trazando las coordenadas claves del diálogo entre la poesía urbana de Efraín Huerta y su contexto cultural, es decir, lo concerniente al contexto enunciativo y proseguiremos con el análisis textual de los poemas en tanto enunciación discursiva. En el primer apartado nos referiremos a Efraín Huerta como el sujeto social que se vale de la poesía para emitir su mensaje, mientras que en los siguientes nos ocuparemos del mensaje poético mismo como texto concreto, es decir, como artefacto semiótico, almacenador y generador de sentido al mismo tiempo (Lotman).

${ }^{1}$ Iuri Lotman desarrolla su concepto de cultura basándolo en una homologación con el funcionamiento del texto. Este no es mero depósito de mensajes, sino dispositivo generador de sentido. Véase La semiosfera I, p. 94.

${ }^{2}$ La tarea de la semiótica discursiva, apunta Fontanille, es "dar cuenta de la manera en que se organiza la significación en lo que se ha convenido en llamar discursos, es decir, con más precisión, 'objetos’ semióticamente observables, sean objetos construidos o prácticas significantes 'espontáneas..” (Soma y sema 113). 
Nuestro análisis se sitúa propiamente en esta segunda etapa pues tiene como propósito primordial explicar la forma en que se produce la significación en el interior de los textos poéticos. Es necesario precisar que la comunicación poética difiere de la comunicación ordinaria al valerse de textos relativamente autónomos (poemas) que escapan al control pragmático de su autor y se orientan a receptores heterogéneos; la figura del poeta pasa a ser un efecto de sentido del texto mismo y por tanto no se corresponde ontológicamente con el autor en su carácter de sujeto social. Es por ello que en este nivel del análisis utilizamos términos como hablante poético, sujeto lírico, sujeto poético o incluso poeta para referirnos al yo discursivo que habla en el poema.

Este análisis considerará dos niveles básicos en la organización del sentido: el semio-narrativo y el discursivo. En el primero examinaremos la relación entre el poeta y la ciudad, que en términos semióticos se enuncia como una relación actancial entre Sujeto y Objeto; se trata, como veremos, de una relación compleja que incluye atracción y rechazo, lo cual es fuente de displacer para el sujeto lírico. En el segundo nivel, ${ }^{3}$ echaremos mano de la semiótica tensiva y de algunos conceptos deleuzianos para dar cuenta de la subjetividad y de las estrategias de resistencia que despliega el sujeto lírico ante una ciudad-patria que se le enfrenta como manjar y como fuerza destructora a la vez.

${ }^{3}$ La semiótica estructural de corte greimasiano considera que todo objeto semiótico presenta un recorrido generativo que incluye dos niveles básicos de significación a los que identifica como estructuras profundas y estructuras de superficie. Las primeras, llamadas semio-narrativas, son abstractas y de carácter lógico, mientras que las segundas, llamadas discursivas, son concretas e incluyen tres procedimientos básicos: actorialización, temporalización y espacialización (Greimas y Courtés, Semiótica. Diccionario Razonado 194-197). En el primer nivel (abstracto) hablamos de actantes y en el segundo (concreto), hablamos de actores o personajes. 


\section{Trazos contextuales: Poesía civil versus poesía solipsista}

La nota más distintiva de la poesía de Efraín Huerta (1914-1982) es indudablemente su vocación cívica y es justo en ese marco discursivo donde afloran sus poemas de contenido urbano. La acentuada orientación social de su poesía contrasta con el esteticismo solipsista asumido por los representantes más visibles de la generación que le precede; me refiero, naturalmente, al grupo de Contemporáneos, cuyos miembros fueron objeto de duras críticas por parte de Huerta en sus primeros años de actividad periodística. ${ }^{4}$ Estamos, evidentemente, ante un relevo generacional. Octavio Paz, amigo personal de Huerta y compañero suyo en proyectos editoriales que marcaron la primera etapa literaria de ambos, registra la presencia de esta nueva generación en la segunda mitad de la década de los años 30 en estos términos:

Entre 1935 y 1938 el observador más distraído podía advertir que una nueva generación literaria aparecía en México: un grupo de muchachos nacidos alrededor de 1914, se manifestaban en los diarios, publicaban revistas y libros, frecuentaban cafés y concurrían juntos a las salas de teatro experimental, a las exposiciones de pintura, a los conciertos y a las conferencias. También asistían — gran diferencia con la generación anterior- a las reuniones políticas de las agrupaciones de izquierda. ("Taller, nueva generación literaria" 3)

La última frase de esta cita es clave para perfilar la nueva sensibilidad. En el año que señala Paz, 1914, nacieron tres escritores fundamentales para identificar esta generación: Efraín Huerta, José

${ }^{4}$ Cristina Pacheco le pregunta a Huerta por qué se dedicó a atacar durante algún tiempo a los poetas del grupo Contemporáneos, a lo que él responde: "Por su apoliticismo. Eso me molestaba mucho. Así que empecé a tirarles desde El Nacional [. . .] Héctor me habló, me hizo reconocer mi error y allí terminó la querella... Luego me hice muy amigo de Villaurrutia y de Novo ("Efraín Huerta. Bajo la dura piel de un cocodrilo" en Huerta. El otro Efraín). 
Revueltas y el propio Octavio Paz. En esta misma constelación podemos agregar, por su cercanía en edad, a otros escritores como Juan Rulfo (1917-1986), Edmundo Valadés (1915-1994) y Elena Garro (1916-1998), entre otros. Todos ellos ${ }^{5}$ se caracterizan por preservar, e incluso consolidar, los estándares estéticos heredados de la vanguardia y por nutrir su producción literaria con los temas apremiantes de la vida política.

El tema político o social retoma sus fueros literarios en las décadas 30 y 40 gracias a la confluencia de varios factores o circunstancias: el examen filosófico de la identidad mexicana que el nuevo nacionalismo demanda de los literatos e intelectuales; la circulación tolerada por el gobierno posrevolucionario de ideas socialistas de procedencia soviética; la guerra civil española y el arribo a México de buen número de artistas e intelectuales provenientes de aquel país; el magisterio de poetas hispanoamericanos y españoles identificados con las vanguardias históricas, pero reconocidos también por la dimensión política de su escritura.

En cuanto a las influencias, Efraín Huerta destaca el fecundo impacto que tuvieron en su poesía Pablo Neruda y Rafael Alberti, a quienes trató personalmente, pero también reconoce el valor de otros poetas de la lengua española como Miguel Hernández, Federico García Lorca, Nicolás Guillén y César Vallejo, entre otros, y fuera de la lengua española expresa su especial admiración por Paul Eluard ("España: Poesía de protesta" y "Efraín Huerta: bajo la dura piel de un cocodrilo. Entrevista con Cristina Pacheco" en El otro Efraín).

Con todo, la poesía civil de Efraín Huerta resulta disonante en el contexto mexicano, y ocasionalmente es descalificada como panfletaria. José Joaquín Blanco advierte que la familia poética de Huerta en lo que respecta a los temas patrióticos no se encuentra en sus coetáneos, sino que remite a la función que tenía la poesía entre los modernistas:

${ }^{5}$ José Luis Martínez suma a esta lista el nombre de Juan de la Cabada quien, si bien nació en 1899, comenzó a ser reconocido en los años cuarenta ("Una generación” p. 2). 
Digamos que esta edición [se refiere a Poesía completa, FCE, 1988] se parece más en cuanto variedad temática y actitud personal ante la poesía a los poetas modernistas que también hablaban de sí mismos y de la patria, de sus héroes y enemigos, de sus hijos y sus anécdotas, antes de que los Contemporáneos volvieran a la poesía un templo de símbolos que no debería estar tan corrompido de cotidianeidad prosaica — para eso servía la prosa - ni de berenjenales ideológicos. (326)

En este punto, es importante acotar que, si bien Huerta recupera la dimensión cívica que alguna vez tuvo la poesía, no lo hace como parte de una retórica gubernamental, legitimadora, sino al contrario, como un ácido reclamo a un país que ha fallado en su función más elemental de cobijar y proteger a sus habitantes, un gobierno que tortura y asesina a sus jóvenes, una ciudad "embustera, peligrosa y maleada" (Huerta, "Atorrantes").

\section{La ciudad como objeto disfórico}

En la poesía urbana de Efraín Huerta, la ciudad no es aludida simplemente como escenografía — de hecho, no encontramos en ella descripciones de avenidas, autos, plazas o edificios-, sino como un convulso conglomerado de seres humanos, atractivo y repelente a un mismo tiempo. La ciudad es, pues, espacio de interacción y negociación para el sujeto lírico: espacio público. En términos de Carrión, es esa la esencia de la urbe: "la ciudad es una comunidad política que se constituye en el espacio público gracias a que en ella la ciudadanía adquiere existencia y a que en ella nace el pensamiento cívico o el espíritu de la ciudad" (200).

Ahora bien, la relación entre el individuo y su comunidad está mediada no solo por intercambios materiales, sino también por una gama de percepciones y afectos. En primer lugar, esa comunidad tiene un nombre, una personalidad, y quienes la integran asumen su pertenencia a ella con menor o mayor entusiasmo. El barrio o la aldea es una especie de extensión de la familia sanguínea a la que pertenece el individuo. El discurso nacionalista establece una 
sinécdoque entre este espacio familiar y uno mayor, que por su extensión es solamente imaginado: el país, que es también la patria. El compromiso con el otro, sea la familia, el barrio o la patria es algo que se adquiere y se fortalece con prácticas simbólicas: canciones, himnos, pinturas, gastronomía, vestimenta, cine, equipos deportivos, poemas...

En México, abundan las canciones sobre pueblos pequeños, ciudades, estados y sobre el país mismo; se trata, por regla general, de cantos festivos que afirman la pertenencia orgullosa a un territorio determinado. En cuanto a la poesía, a raíz de la independencia política del dominio español, la afirmación de los valores patrios fue un imperativo civil de los poetas mexicanos del siglo XIX. La revolución mexicana trae consigo un nuevo nacionalismo que se hace sentir especialmente en la canción vernácula y en el cine. Sin embargo, la literatura no acompaña como los ideólogos quisieran este optimismo. La novela desmantela el mito revolucionario y la poesía se retira del escenario político con el advenimiento de las vanguardias para ocuparse de sí misma y luego regresa a la arena social justamente con la poesía enjundiosa y crítica de Efraín Huerta. La patria en sus poemas no es la aldea apacible, con sus ríos, magueyes y montañas entrañables que pregona el cine nacional, sino lo opuesto: una ciudad convulsa, engañosa, difícil de entender y, por tanto, difícil de tratar en el terreno amoroso.

En este apartado examinaremos la relación que mantiene el hablante o sujeto lírico, con esa instancia simbólica que es depositaria de todos sus amores y desamores: la ciudad. Para ello nos basaremos de inicio en la semiótica greimasiana, según la cual, el sentido de todo discurso se organiza en el nivel profundo como relato. ${ }^{6}$

${ }^{6}$ Raúl Bueno muestra la pertinencia de este principio metodológico en el análisis que hace de varios poemas adscritos a la vanguardia hispanoamericana. En su libro Poesía hispanoamericana de vanguardia considera que los componentes del esquema actancial "dan cuenta de la estructura narrativa de no importa qué relato, sea cuento, novela, drama, historia, relación, nota informativa, etc., y aún de discursos que nunca habían sido entendidos en términos de relato, como la filosofía y el discurso científico" (41). Más adelante puntualiza: "Volviendo a nuestro tema 
Dicho muy resumidamente, en toda acción humana podemos identificar seis componentes (Greimas 276-281): Un Sujeto que desea un Objeto; un Destinador que comunica a un Destinatario ${ }^{7}$ el valor que tiene ese Objeto; los otros dos actantes, Ayudante y Oponente, son las fuerzas que participan a favor o en contra del Sujeto en la obtención de su Objeto. A la luz de este esquema, la poesía urbana de Efraín Huerta se nos presenta como un Sujeto separado de su Objeto. En todos estos poemas la voz poética expresa el pesar (disforia) que le ocasiona esta disyunción. El Destinador es todo el legado cultural que incita al poeta (Sujeto) a rendirle culto a la patria (Objeto). En cuanto a las fuerzas favorables (Ayudante), podríamos decir que son las habilidades o recursos poéticos con que cuenta el poeta. En lo referente al Oponente, la situación se complica: es la propia ciudad, la propia patria. Justamente en esta paradoja consiste la mayor dificultad que enfrenta el Sujeto, la cual en el nivel discursivo se figurativiza como frustración, rabia, decepción.

La equivalencia que venimos insinuando entre la ciudad y la mujer amada no es mero recurso expositivo, sino que se asienta en el análisis mismo de la poesía urbana de Huerta, la cual adopta la forma de un discurso amoroso: el poeta se dirige a la ciudad como lo haría un amante dolido que reclama a la amada su ingratitud. Lo que resulta de esta desavenencia es un mensaje suplantado: el emisor reprime el impulso original de emitir una declaración dulce y gozosa, y en su lugar lanza un amargo improperio. El poema "Declaración de odio", por ejemplo, uno de los más estridentes y

cabe agregar que aún la poesía lírica pura, aquella definida por Barthes como 'la amplia metáfora de un solo significado’ (1966: 25) y entendida por Rewet como el conjunto de transformaciones expansivas de una misma proposición, como 'te amo’ (1972: 199) se sirve del relato y, por ello, puede ser analizada y explicada en términos de la semiología del relato" (54). Las fuentes citadas por Bueno corresponden a: Barthes, Roland et al. "Introduction a l'analyse structurale des résits". Comunication 8, Seuil, 1966; y Rewet, Nicolás. Langage, musique, poésie. Seuil, 1972.

7 Nótese que se trata de funciones del nivel actancial, no de personajes o actores. Las funciones de Destinatario y Sujeto suelen ser asumidas por un mismo personaje. 
también uno de los más reproducidos en las compilaciones que se hacen del autor, comienza con una especie de soliloquio en que el amante expresa su estado de decaimiento:

Estar simplemente como delgada carne ya sin piel, como huesos y aire cabalgando en el alba, como un pequeño y mustio tiempo duradero entre penas y esperanzas perfectas. $(79-80)^{8}$

La ciudad-mujer opera con un principio opuesto a la vida; actúa como un sistema lesivo que merma las fuerzas vitales del Sujeto:

Esta ciudad de ceniza y tezontle cada día menos puro, ciudad de acero, sangre y apagado sudor. (80)

¡Los días en la ciudad! Los días pesadísimos como una cabeza cercenada con los ojos abiertos.

Estos días como frutas podridas.

Días enturbiados por salvajes mentiras. (81)

Corrupción y falsedad son los atributos más distintivos de esta amada terrible. Es descrita como una "vieja díscola y aparatosa", como "hervidero de envidias", y "páramo sofocante" en que todo se pudre. Sus albas, lejos de anunciar pureza y esperanza, emulan "vírgenes hipócritas". La ciudad es, además, sorda: "nido blando en que somos como palabra ardiente desoída" (81). Nótese que la voz poética se ha pluralizado en un nosotros. Esto prepara el terreno para iniciar la siguiente estrofa con un cambio de enunciación estratégico: un sujeto colectivo se dirige ahora a la ciudad como un tú inequívoco y le declara su odio con una frase desconcertante: "Te declaramos nuestro odio, magnífica ciudad" (81).

En este enunciado convergen claramente dos sentimientos contrarios, lo cual intensifica su potencial expresivo. Tal pareciera

${ }^{8}$ Con excepción del poema "Juárez-Loreto", que fue consultado en el libro Poesía completa, todas las citas de poemas corresponden al libro Poesía 1935-1968. 
que el hablante experimentara un descuido en medio de toda una arenga de vituperios contra la amada y emergiera de pronto el sentimiento reprimido. Otra manera de entenderlo es que este odio no es un sentimiento estrictamente personal o individual, sino que comporta una dimensión social, lo cual se sustenta en la aparición de un sujeto enunciador plural. Desde luego, el hecho de que en otros poemas este sentimiento se enuncie en primera persona no invalida lo que aquí observamos. En realidad, todo sentimiento discursivizado, por el solo hecho de emerger a la conciencia a través de la palabra, constituye una expresión social. Sin embargo, como bien señala Raymond Williams, la semiosis de la poesía - y el arte en general - se caracteriza por valerse de procedimientos orientados a registrar y comunicar experiencias presentificadas, es decir, en proceso, lo cual va a contrapelo de las formas de representación que buscan dar cuenta de lo social estructurado, es decir, no se formula como un sistema explicativo:

La hipótesis [de las “estructuras del sentir”] presenta una especial relevancia con respecto al arte y la literatura, donde el verdadero contenido social, en un número significativo de casos, de este tipo presente y efectivo, y sin que ello suponga pérdidas, no puede ser reducido a sistemas de creencias, instituciones o relaciones generales implícitas, aunque puede incluir a todas ellas como elementos vividos y experimentados. (156)

En el caso de Efraín Huerta, su poesía urbana no tiene como propósito describir la ciudad o proporcionar información sobre ella, sino profundizar en la experiencia anímica de habitarla, y lo que nos reporta es una experiencia disfórica. ${ }^{9}$ El desagrado que ahí

${ }^{9}$ En Semiótica. Diccionario razonado de la teoría del lenguaje, Greimas y Courtés definen la disforia como "el término negativo de la categoría tímica" (230), es decir, corresponde a la valoración negativa de la foria o sentir. Contraria a la euforia, la disforia comprende toda forma de desagrado o displacer. En Semiótica de las pasiones, Greimas y Fontanille llaman foria a "este 'más acá' del sujeto de la 
se expresa, aun cuando se hace en un lenguaje sensorial, no tiene que ver con la arquitectura de la ciudad, su escenografía o sus incomodidades materiales, sino con cuestiones éticas. El poeta se relaciona con la ciudad no como espacio geométrico, sino como espacio cívico, como microcosmos del país, es decir, de la patria. Uno de los poemas más elocuentes es "Avenida Juárez". El poema comienza de esta manera:

Uno pierde los días, la fuerza y el amor a la patria, el cálido amor a la mujer cálidamente amada la voluntad de vivir, el sueño y el derecho a la ternura. (178)

Este sentimiento de desamor es experimentado por el sujeto lírico mientras camina por la calle que da título al poema. La significación, de acuerdo a la semiótica tensiva, se articula en la frontera de un exterior y un interior que corresponden, respectivamente, al plano de la expresión y al plano del contenido. El exterior se percibe (exteroceptividad) y el interior se siente (interoceptividad). ${ }^{10}$ La línea que media entre uno y otro es el cuerpo propio, el cual no debe confundirse con el cuerpo físico del sujeto; es un concepto semiótico para nombrar la línea que separa y une ambos universos. El cuerpo propio es el posicionamiento del sujeto hablante, un punto de referencia móvil cuyas propiedades "se pueden designar globalmente con el término propioceptividad" (Fontanille, Semiótica 39). De acuerdo con este modelo explicativo, el amor a la patria, lo mismo que el amor a la amada y el amor a la vida constituyen el significado complejo de ese extenso significante que es la ciudad. La ciudad es, pues, algo más que un conjunto de edificios y vialidades para la circulación: es un signo complejo o más exactamente un texto. Violli lo formula en estos términos:

enunciación" (19), con lo que se refieren al cuerpo sintiente.

${ }^{10}$ Para profundizar en estos conceptos puede consultarse el sugerente ensayo de Raúl Dorra "Entre el sentir y el percibir” en: Landowski, compilador. Semiosis, estesis, estética. EDUC / BUAP, 1999. 
No es sólo un signo, algo que tenga un significado único y un significante bien determinado y estable, ni, sin duda, un mensaje único que alguien lleva a otros, sino un texto, etimológicamente un tejido (recordemos la expresión: tejido urbano) o más bien un entrelazamiento de elementos de sentido relacionados entre sí. (1030)

La poesía de tema urbano, más que una representación verbal de la ciudad es, pues, una intervención creativa en la producción cotidiana de ese gran texto que es la ciudad. El Objeto ciudad incluye como parte constitutiva la representación que sus habitantes hacen de ella: deviene objeto semiótico. Para la clarificación de este punto, conviene recurrir al modelo triádico de Peirce. ${ }^{11}$ La poesía de Efraín Huerta, al igual que todo texto que versa sobre la ciudad, alimenta el repertorio semántico (Interpretante) del sujeto o intérprete (lector), quien se ve impelido a resemantizar la palabra "ciudad" (Representamen) para que esta remita adecuadamente al Objeto de referencia, un objeto en continua transformación. La naturaleza discursiva de la ciudad, advierte Violli, hace de esta un texto complejo e inestable: "un texto viviente, en continua transformación, nunca idéntico a sí mismo" (1030).

El paseante del poema "Avenida Juárez" lee en este texto-ciudad. ¿Cómo se da esa lectura? Llama la atención que el paseante no describe las aristas objetivas de la Avenida en forma directa, no

${ }^{11}$ El concepto de signo que propone Peirce consta de tres elementos: Representamen, Objeto e Interpretante. El Representamen es el estímulo (palabra, señal, etc.) que ordinariamente llamamos signo; este tiene como función sustituir o estar en lugar de otra cosa. El Objeto es la cosa material o imaginaria representada. Lo peculiar del modelo peirciano es que concibe el Objeto no como algo fuera del signo, sino como parte constitutiva de él. Finalmente, el Interpretante, es el repertorio de saberes, imágenes, convenciones, etc. que permiten al sujeto establecer conexiones entre el Representamen y el Objeto. El Interpretante se ubica pues en las mentes de los sujetos o intérpretes que interactúan (Peirce 2125). Es importante no confundir Interpretante con Intérprete. Este último es el sujeto que produce o utiliza los signos. 
adopta el modelo descriptivo del espacio mensurable, sino que aprehende el ser de la avenida con un lenguaje más cercano al cuerpo.

Hay en el aire un río de cristales y llamas, un mar de voces huecas, un gemir de barbarie cosas y pensamientos que hieren (178)

Más adelante, los elementos de la ciudad adquieren fisonomías más específicas y se define mejor el sentimiento que estas provocan en el paseante:

Marchar hacia la condenación y el martirio, atravesado por las espinas de la patria perdida ahogado por el sordo rumor de los hoteles donde todo se pudre entre mares de whisky y de ginebra (179)

La segunda línea resume magistralmente el poema completo. Desplazarse por la ciudad, significa un martirio anímico para el sujeto ya que esta le resulta ajena. La ciudad que se le ofrece, invadida por productos y paseantes extranjeros, contrasta con la idea de una ciudad cercana y amorosa:

Uno mira los árboles y la luz, y sueña con la pureza de las cosas amadas

y la intocable bondad de las calles antiguas con las risas antiguas y el relámpago dorado de la piel amorosamente dorada por un sol amoroso. $(179-180)$

Volviendo al esquema narrativo inicial, tenemos que el poema nos presenta un cuadro irónico: en el plano físico, el Sujeto ha logrado la unión con su Objeto (el poeta pasea por una de las avenidas más emblemáticas de la ciudad), pero este mismo contacto provoca una radical separación en el plano afectivo. La ciudad como Objeto deseado se ha escindido en dos: una realizada, alejada del deber ser, y una imaginaria o potencial, que es la patria amorosa deseada por el poeta: 
Todo parece morir, agonizar, todo parece polvo mil veces pisado.

La patria es polvo y carne viva, la patria

debe ser, y no es, la patria

se la arrancan a uno del corazón

y el corazón se lo pisan sin ninguna piedad (180-181)

En el pasaje encontramos un elemento que de nuevo nos regresa al esquema narrativo: la patria auténtica alguna vez le perteneció al poeta y ahora advierte que le ha sido arrebatada. ¿Quién o qué la ha arrebatado? El poema reserva la respuesta para la última estrofa. Esta se enuncia en forma diferente: lo que parecía soliloquio al inicio del poema se manifiesta ahora como una arenga indignada que se dirige a un tú plural, compuesto por un grupo de individuos a los que el poeta llama hermanos:

Pues todo parece perdido, hermanos, mientras amargamente, triunfalmente, por la Avenida Juárez de la ciudad de México - perdón, Mexico City-

las tribus espigadas, la barbarie en persona, los turistas adoradores de "Lo que el viento se llevó", las millonarias neuróticas cien veces divorciadas, los gangsters y Miss Texas, pisotean la belleza, envilecen el arte ...

y lo dejan a uno tirado a media calle con los oídos despedazados y una arrugada postal de Chapultepec entre los dedos. (181-182)

Retornando al esquema actancial, observamos que este tú plural no se sitúa en el Objeto, sino que constituye una expansión del Sujeto. De la misma manera que el objeto ciudad se escinde en dos, la realizada y la idealizada, el sujeto poeta también se duplica, lo cual le permite dar forma discursiva a su emotividad. La esencia del malestar que experimenta la voz poética no deriva de un sentimiento nos- 
tálgico, anclado en la oposición romántica entre campo y ciudad, sino que resulta de una lectura política. La modernidad que muestra la ciudad es fruto podrido porque en ella se respira el colonialismo de que es presa el país a manos del poderío yanqui.

Si bien la injerencia colonialista es un pecado patrio indignante que se señala con insistencia en la poesía de Huerta, no es el único. La pobreza, la prostitución, la mendicidad, el cansancio, el abuso policial, el miedo, el crimen, son síntomas dolorosos de un sistema social despiadado, todo lo cual constituye una auto-traición. Además de los poemas ya mencionados, el reclamo a la patria-ciudad aparece en muchos otros, especialmente en aquellos que engrosan la llamada poesía de protesta: “iMi país, oh mi país!”, "Amor, patria mía", "Elegía de la policía montada".

La ciudad en la poesía de Efraín Huerta es el todo y la parte, como en los fractales: es la proxeneta y la joven prostituta, la victimaria y la víctima, la asesina y el cadáver. Es una totalidad grandiosa estrangulada por la abyección y el dolor. Una de las imágenes más estrujantes que expresan la relación del poeta con la ciudad es justamente la encarnada por la joven prostituta del poema " $\mathrm{La}$ muchacha ebria":

Este lánguido caer en brazos de una desconocida, esta brutal tarea de pisotear mariposas y sombras y cadáveres; este pensarse árbol, botella o chorro de alcohol, huella de pie dormido, navaja verde o negra; este instante durísimo en que una muchacha grita, gesticula y sueña por una virtud que nunca fue la suya (89)

\section{La ciudad utópica y el sujeto en ruinas}

A la ciudad abyecta que hemos expuesto se opone la ciudad ideal o utópica. Esta oposición nos da la pauta para retomar el esquema narrativo en que se organiza y produce el sentido o más bien una dimensión del sentido. Desde este ángulo, el Sujeto asume la función de Destinador y se dirige a la ciudad como un Sujeto al que intenta persuadir de que debe cambiar la naturaleza de su ser. En el 
poema "Declaración de amor", que aparece inmediatamente después de la "Declaración de odio", la voz poética se dirige en forma persuasiva a esa ciudad oculta que pervive en el corazón mismo de la ciudad visible. El hablante lírico se dirige a esa ciudad como a una dama sensible: Ciudad que llevas dentro
mi corazón, mi pena,
la desgracia verdosa
de los hombres del alba,
mil voces descompuestas
por el frío y el hambre. (83)

Es importante observar lo que ocurre con el hablante poético. Se presenta ante la ciudad ya no como una sola voz, sino como una legión: la de los "hombres del alba". El sujeto hablante se atomiza en miles de voces. Este proceso de auto fragmentación en el sujeto se corresponde con un movimiento similar en el objeto ciudad, la ciudad no es evocada con sus trazos rectangulares y su luminosidad, sino que se actualiza también como materia primigenia:
Ciudad que lloras, mía, maternal, dolorosa, bella como camelia y triste como lágrima, mírame con tus ojos de tezontle y granito caminar por tus calles como sombra o neblina (83)

En términos de Deleuze, el sujeto experimenta una desterritorialización ${ }^{12}$ hacia un espacio indefinido cuya liminalidad se expresa en

12 Desterritorialización consiste en el abandono de un dominio u orden establecido. Se le identifica también como línea de fuga. 
términos temporales: el alba, un estado intermedio entre la noche y el día. En el sistema discursivo ordinario, lo opuesto a la ciudad es el campo. El hablante poético no se posiciona, sin embargo, en éste, para esgrimir sus denuestos contra la urbe, lo cual sería tanto como oponer una estructura a otra, sino que postula un espacio roto o desestructurado, por decirlo así: un espacio en penumbra que queda fuera de los reflectores citadinos. El alba es quizá la imagen más polisémica y una de las más recurrentes en la poesía de Efraín Huerta. De hecho, da título a dos poemarios: Línea del alba (1936) y Los hombres del alba (1944). La mayoría de los poemas que aquí comentamos pertenecen a este último libro. El alba es aquí un umbral desde el cual puede avizorarse esa otra ciudad matricial:

Los hombres que te odian no comprenden cómo eres pura, amplia, rojiza, cariñosa, ciudad mía (84)

En distintos poemas podemos encontrar esbozos de esa ciudad utópica, especialmente en aquellos que versan sobre otras ciudades: San Antonio, Texas en "La lluvia", Varsovia en "Palomas sobre Varsovia", Praga en "Praga, mi novia", Lídice en "La sílaba dorada", Budapest en "El río y la paloma", etc. Carlos Montemayor considera que varios de estos poemas se alejan del urbanismo genuino y responden más a la militancia política del autor, proclive al comunismo soviético. La retórica, según el crítico, ha desplazado en estos poemas a la poesía:

Su vocación urbana se hace a un lado para dejar paso a su profesión de fe política, no al encuentro con ciudades, calles, hombres, realidades. En poemas como Palomas sobre Varsovia, La sílaba dorada y El río y la paloma, no hay ciudad, no hay la compenetración intensa con que es capaz de ver las ciudades que siente, no en que cree. (16-17)

Ciertamente, la densidad semántica de los poemas que menciona es más ligera ya que ha sido superado el conflicto axiológico entre el sujeto lírico y su mundo. En ellos se representa ya realizada la 
ciudad ideal que se evoca en los poemas de Los hombres del alba. En "Palomas sobre Varsovia" leemos:

Te veo crecer, te oigo crecer como la hierba, ciudad preñada de siglos, madre de los albañiles, madre del mármol y del hierro, de los nuevos árboles y de las canteras que suenan a gloria. (142)

La lectura de estos poemas desestimados como panfletarios por algunos críticos nos confirma la predilección del universo poético de Huerta por la ciudad como espacio y forma de convivencia humana. Aún en los poemas más ásperos de Los hombres del alba se deslizan discretamente aromas y acentos conciliatorios. No es la ciudad en sí, sino el sistema social lo que está podrido, pero el sujeto poético solo puede valerse de ritmos y sensaciones del ámbito citadino para vivenciar su reprobación.

Visto desde la dimensión pragmática, ${ }^{13}$ lo esperable de la ciudad es que retribuya satisfacción y bienestar a sus habitantes, ya que ha sido producida por ellos. Lo contrario, es decir, un trato hostil, es algo inesperado que desestabiliza al sujeto. De acuerdo a la semiótica tensiva, este rechazo no constituye una acción, sino un evento o acontecimiento. El evento es algo imprevisto que toma por sorpresa al sujeto y lo despoja de las competencias modales que lo definen como sujeto de acción: el querer, el poder, el saber. Lo propio del evento, señala Zilberberg "consiste en realizarse como una intrusión, como una 'penetración' (Valéry), como una 'brusquedad eficaz’ (Focillon)” (34). El sujeto narrativo clásico participa de un programa en el que tiene como cometido llegar a un nuevo estado. El acontecimiento, por el contrario, cancela ese programa y arroja al sujeto del estado en que se encuentra. El acontecimiento adviene

${ }^{13}$ Fontanille considera que el discurso organiza la experiencia, atravesado con base en tres racionalidades: la acción (dimensión pragmática), la pasión (dimensión del acontecimiento) y la cognición (dimensión cognitiva) (Semiótica del discurso 161-162). 
como algo no programado por el sujeto, "lo desliga de sus competencias modales y lo transforma en sujeto del padecer" (35-36).

El sujeto del padecer es, por excelencia, el sujeto pasional. Es este el sujeto lírico que aparece en la mayoría de los poemas urbanos de Huerta: un ser disminuido y fragmentado. Tan sólo en el poemario Los hombres del alba, encontramos cuatro poemas con el título "canto de abandono" con el respectivo numeral antepuesto. En los cuatro, el hablante se identifica con elementos descoloridos, gaseosos, pulverizados o con líquidos. Veamos un breve pasaje de cada uno de estos poemas:

Mi voz en la saliva del olvido, como pez en un agua de naufragio (75)

- .

Soy una noche blanca moribunda, voz de encono y ruptura, voz de alba, mustia y líquida voz del abandono (77)

.

por distraído y lento como el humo (78)

...

Estoy con las heridas claras del abandono y el repetido canto burlón de la ceniza (93)

En otro poema directamente relacionado con el tema del yo, "Problema del alma", leemos:

Y sin verte, alma mía, mi sueño disecado es una rosa huérfana, una brasa cansada, dolorida, triste músculo frío, lacerado por crueles, crueles lluvias y llantos errabundos (94)

No se trata, sin embargo, de una autoflagelación masoquista o chantajista. El proceso de empequeñecimiento y fragmentación 
que lleva a cabo el sujeto lírico puede entenderse como un devenir-imperceptible, en términos deleuzianos. El devenir imperceptible como el devenir animal y otros devenires constituyen líneas de fuga ante el avasallamiento de un proceso estructurante. Es una especie de huida defensiva, en el entendido de que huir es una acción productiva: "Pero huir no significa, ni muchísimo menos, renunciar a la acción, no hay nada más activo que una huida... Huir es trazar una línea, líneas, toda una cartografía. Sólo hay una manera de descubrir mundos: a través de una larga fuga quebrada. (Deleuze y Parnet, Diálogos 45). Se trata, siguiendo la terminología de Deleuze, de una desterritorialización, lo que conlleva la creación de un lugar entre, un lugar desierto, no estructurado. El poema "Esta región de ruina" parece describirlo:
Nada ni nadie aquí, bajo este vientre o cielo a fuego lento.
Nada; tan solo el bronco sueño de los desarraigados, alienta, se agita en esta blanca región contradictoria, de niebla y besos, de voluptuoso vaho sobrehumano y voraz, como si flores turbias, alcohol y muerte a ciegas la nutriesen. (100)

En este espacio entre, anida lo indeterminado, lo impredecible. Su debilidad y su fuerza radica justamente en eso. Es un espacio de sobrevivencia habitado por desarraigados. Ser desarraigado quiere decir dejar de pertenecer al sistema arbóreo y extenderse como hierba o como plaga (Deleuze y Guattari, Mil mesetas 9-25). Los pobladores de este desierto son, pues, nómadas: multiplicidades. En el poema "Los hombres del alba" encontramos una rápida descripción de estos pobladores:

Son los hombres del alba.

Los bandidos con la barba crecida

y el bendito cinismo endurecido,

los asesinos cautelosos 
con la ferocidad sobre los hombros,

los maricas con fiebre en las orejas

y en los blandos riñones,

los violadores,

los profesionales del desprecio,

los del aguardiente en las arterias,

los que gritan, aúllan como lobos

con las patas heladas.

Los hombres más abandonados, más locos, más valientes:

los más puros. (87)

Nótese la intensidad expresiva que generan los calificativos adheridos al sustantivo por una especie asociación fortuita en "el bendito cinismo endurecido", la aproximación a la animalidad en "los que gritan, aúllan como lobos con las patas heladas" y la valoración inesperada con que remata la estrofa: "los más puros". Se trata, pues, de sujetos trasgresores para quienes las instituciones sociales han perdido solidez, seres transfronterizos en estado de perpetua transición, seres a punto de dar un salto hacia lo animal, lo sagrado, la brutalidad o la inocencia; he ahí su pureza.

Nuestra imaginación ubica topográficamente estos espacios en la periferia de la ciudad. Sin embargo, la poesía de Huerta coloca este desierto no en la orilla, sino en el corazón de la ciudad. Esto ocurre gracias a que la mirada se ha desplazado del plano espacial al temporal: es la misma ciudad física, pero en una hora específica: el alba. En esa hora, la ciudad es región en ruinas, tierra de nadie. No se trata, sin embargo, de un esquema estático y absoluto, ya que los hombres y mujeres desterritorializados en esa zona intermedia, pueden ser también avizorados a plena luz del día. Un ejemplo elocuente es lo que ocurre en el poema "Juárez-Loreto", perteneciente al libro Los eróticos y otros poemas (1974). El hablante poético aborda un autobús de esa ruta y le ocurre un incidente jocoso-erótico con una mujer que se dedica al robo. 
La del piernón bruto me rebasó por la derecha:

rozóme las regiones sagradas, me vio de arriba abajo

y se detuvo en el aire viciado: cielo sucio

de la ruta 85 , donde los ladrones

me conocen porque me roban, me pisotean

y me humillan: seguramente saben

que escribo versos: ¿Pero ella? ¿Por qué

me rebasa en esa forma tan desleal? ¿Por qué

me faulea, madruga, tumba, habita, bebe? (Poesía completa 300)

El hablante poético describe el pelo y los ojos de la mujer. El primero, con evocaciones de destellos leoninos y los segundos, con sugerencias de una vida nocturna y licenciosa, para rematar con una imagen sorprendente que conjuga valores estéticos y éticos contradictorios, que delatan su parentesco con los "hombres del alba":

Tiene el pelo dorado de la madrugada

que empuña su arma y dispara sus violines.

Tiene un extraño follaje azul-morado

en unos ojos como faroles y aguardiente.

Es un jazmín angelical, maligno, arrancado del zarzal en ruinas. (301)

La mujer continúa con su juego erótico, rozando su cuerpo mientras el vehículo cruza por calles y estaciones que ostentan nombres de personajes célebres. El sujeto lírico modifica graciosamente su punto de vista sobre el robo:

Alabados sean los ladrones, dice Hans Magnus.

Pues que lo sean: los veo hurtar carteras, relojes, orejas, pies, nalgas iridiscentes, bolígrafos, anteojos, y ella, que debe llamarse Escaldada, ni se inmuta.

Vuelve al roce, al foul, al descaro;

se alisa la dorada cabellera

(¡Coño, carajo, caballero, qué cabellera de oro!) (301) 
El poema nos muestra una nueva faceta en la poesía de Efraín Huerta, que no cancela, sino culmina su orientación libertaria: el humorismo. ${ }^{14}$ En los poemas de los años cuarenta la tensión entre el hablante poético y la ciudad se da en un tono apesadumbrado, fúnebre. En este poema de la década de los setenta, en cambio, asistimos a una ramificación rizomática, para seguir con Deleuze, que se dispara por una ruta antisolemne. Es inaudita la libertad que debe anidar en el corazón de esta chica que desprecia bárbaramente los grandes símbolos de la ciencia y la cultura en que la ciudad asienta su prestigio; lejos de concederles alguna reverencia, se afana solo en robar lo que puede a los pasajeros:

Se marea, se hegeliza, se newtoniza

y pasamos por donde Maimónides y Hesíodo

¡y pone todavía más cara de estúpida

cuando Alejandro Dumas, Poe y Moliere y los cines cercanos!

Malditilla, malditilla, putilla camionera,

vergüenza seas para las anchas avenidas

que son Horacio, Homero y, caray (aguas, aguas), Ejército

Nacional! (301)

Y por si fuera poco, esta "malditilla" se distrae ahora provocando con sus fricciones el incendio erótico de un poeta ${ }^{15}$ culto y formal:

Porque luego de tus acuciosos frotamientos

y que cada quien llegó a donde quiso llegar

(para eso estamos y vivimos en un país libre)

${ }^{14} \mathrm{Al}$ respecto, Lozoya Saldaña apunta: "En tanto, Rafael Solana se equivocó al decir en 1944 en el prólogo de Los hombres del alba que Huerta no tenía sentido del humor y que nunca sería popular, pues al cabo del tiempo, se develaría como uno de los poetas más irónicos y su popularidad alcanzaría tintes notables e insospechados en aquella época. Prueba de ello son sus poemínimos que arrancan carcajadas frescas y espontáneas" (69).

${ }^{15}$ No me refiero al autor Efraín Huerta, sino al personaje que aparece representado en el poema: alguien que escribe versos. 
hube de regresar al lugar del crimen

(así llamo a mi departamento de Lope de Vega),

y pues me vine, sí, me vine lo más pronto posible

en medio de una estruendosa rechifla celestial. (302)

Ahora bien, aunque abierta a todas las posibilidades, incluidas la erótica y la humorística, la comunidad nómada de los hombres (y mujeres) del alba, vibra con un ethos convulso que conjuga varios sentimientos y emociones: la ira, la ternura, el odio, el amor, la amargura, la angustia. Estos se resuelven en un sentimiento global que les da sentido y les dignifica: el desprecio. Ellas y ellos son los profesionales del desprecio:

Del gesto de aquel hombre que solloza

Brota una espiga sorda, desnutrida,

Una doliente espiga, frágil, suave, una verdad perfecta: es el desprecio.

...

Y ha terminado la oración:

Esta flor es un tempo y un abismo,

Una brillante consigna y un apretón de manos ...

Junto a la flor del odio y el amor, La tierna flor del ansia y el Desprecio ("Poema del desprecio" 106-107)

El odio de que hablan los poemas citadinos de Huerta no es, pues, el odio común y corriente que se dirige a individuos particulares, sino una especie de contención amorosa en respuesta a la exclusión social. El canto que de ahí brota no puede ser dulce y exquisito, sino amargo como el desprecio y como las pócimas curativas. En el poema "La raíz amarga" (1962), Huerta sintetiza en tres breves líneas su poética urbana:

Mordamos la raíz amarga, duro cristal, seca raíz del alba, amorosa y angélica raíz (196) 


\section{Conclusiones}

La poética de Efraín Huerta es fundamentalmente citadina. Sus poemas más conocidos y celebrados son los de tema urbano. Los que hemos analizado en este trabajo son buenos ejemplos. ${ }^{16}$ La crítica suele etiquetar a Huerta como el poeta de la ciudad, y se piensa específicamente en la Ciudad de México. Sin embargo, al leer su obra con detenimiento, podemos observar que esta distinción, por bienintencionada que parezca, conlleva el riesgo de limitar sus alcances: hemos visto que la ciudad en su poesía es una metonimia del país y que el país es la vida social misma.

Es claro que lo que está en la mira de la poesía de Huerta no es estrictamente el paisaje urbano capitalino, sino el individuo y su organización social. La suya es una poesía eminentemente política con todo lo que esta entraña en el campo de la estesis y la afectividad. ${ }^{17}$ Nuestra tarea ha sido examinar la manera en que se organiza la significación a partir de estos códigos sensibles, para lo cual hemos recurrido a diversas semióticas, pero teniendo como anclaje flexible el modelo greimasiano en sus dos vertientes: la estructuralista de los años sesenta, de tipo lógico-semántico, y la actual, orientada al estudio del discurso sintiente, identificada como semiótica tensiva.

Se trata en cierto modo de dos lecturas contrapuestas. Por una parte, hemos observado que el sentido se organiza como un relato

${ }^{16}$ Una manera de corroborarlo es revisando las antologías. Tomemos en cuenta tres, dos mexicanas y una hispanoamericana: Poesía en movimiento, compilada por Octavio Paz y otros; Poesía mexicana II 1915-1979, de Carlos Monsiváis; y Antología de la poesía hispanoamericana contemporánea, compilada por Julio Ortega. De los poemas mencionados en este trabajo, tenemos que "Declaración de odio" aparece en las tres compilaciones; "Los hombres del alba" y "La muchacha ebria", en las primeras dos; y en la antología de Monsiváis figuran "Avenida Juárez" y "Juarez-Loreto".

17 José Emilio Pacheco ha llamado la atención sobre la marcada presencia de prójimos en la poesía de Huerta: "Huerta es de aquellos poetas para quienes los demás existen. Su poesía está llena de gente No le da vergüenza hablar de sus prójimos más próximos, sobre todo sus hijas y sus hijos" (4). 
en el que el sujeto lírico se encuentra separado de su objeto, entiéndase la ciudad, y se esfuerza por alcanzar la unión. Por la otra, hemos observado que el sujeto es sorprendido por el absurdo rechazo de la ciudad, un objeto que él ha contribuido a crear. En el primer caso, lo conducente para el sujeto es idear estrategias para lograr su objetivo, entre las que se hace notar la asociación con otros desarraigados. En el segundo, el sujeto es despojado de sus competencias cognitivas y queda preso en los vaivenes de su subjetividad. Se observa que su yo entra en un proceso de desintegración a la vez que se multiplica en millares de voces: "Soy el llanto invisible/ de millares de hombres" ("Declaración de amor" 83).

En el primer esquema el sujeto es pro-activo, mientras que en el segundo se fragmenta en un plan de resistencia. En el primero "los hombres del alba" constituyen una guerrilla que se dispone al ataque; en el segundo son una horda sin proyecto definido, pero indestructible como las hormigas o las cucarachas. ¿Cuál de las dos lecturas es la correcta? De acuerdo con el planteamiento inicial de Greimas, el nivel semio-narrativo rige al figurativo, que es más superficial. Sin embargo, el análisis realizado nos permite apreciar que se trata de sistemas organizativos interdependientes.

La interacción entre los dos sistemas semióticos descritos explica hasta cierto punto el dinamismo semántico de la poesía urbana de Efraín Huerta, es decir, su gran vitalidad para renovar su significación en contextos culturales nuevos, lo que asegura su trascendencia ética y estética.

\section{Bibliografía}

Bueno, Raúl. Poesía hispanoamericana de vanguardia. Latinoamericana Editores, 1985.

Carrión, Fernando. "El espacio público es una relación no un espacio". Derecho a la ciudad. Una evocación de las transformaciones urbanas en América Latina, de Fernando Carrión Mena y Manuel Damert-Guardia, Clacso / IFEA, 1919, pp. 191-219.

Deleuze, Gilles y Claire Parnet. Diálogos. Pre-textos, 1980. 
Deleuze, Gilles y Félix Guattari. Mil mesetas. Capitalismo y esquizofrenia. Pre-textos, 2004.

Dorra, Raúl. "Entre el sentir y el percibir". Semiótica, estesis, estética, compilado por Eric Landowski y Raúl Dorra, EDUC / BUAP, 1999, pp. 253-267

Fontanille, Jacques. Semiótica del discurso. Fondo Editorial / Universidad de Lima, 2006.

. Soma y sema. Figuras semióticas del cuerpo. Fondo Editorial / Universidad de Lima, 2008.

Greimas, Algirdas Julien. Semántica estructural. Investigación metodológica. Gredos, 1987.

Greimas, Algirdas y Joseph Courtés. Semiótica. Diccionario razonado de la teoría del lenguaje. Gredos, 1982.

Greimas, Algirdas y Jacques Fontanille. Semiótica de las pasiones. De los estados de cosas a los estados de ánimo. Siglo Veintiuno, 1991.

Huerta, Efraín. "Atorrantes y cavernícolas". El otro Efraín, Fondo de Cultura Económica, 2014.

- El otro Efrain. Antología prosística. e-book, prólogo y edición de Carlos Ulises Mata. Fondo de Cultura Económica, 2014, play. google.com/books/reader?id=W795BgAAQBAJ\&pg=GBS.PT509 . Poesía 1935-1968. Secretaría de Educación Pública / Joaquín Mortiz, 1986.

. Poesía completa. Fondo de Cultura Económica, 2004.

Lozoya Saldaña, María Lorena. "La urbana pasión de Efraín Huerta." Esencia y espacio, enero - junio 2007, pp. 65-74, www.yumpu.com/es/document/read/14474196/en-linea-revista-esencia-y-espacio-instituto-politecnico-nacional

Lotman, Iuri. La semiosfera I. Semiótica de la cultura y del texto. Cátedra, 1996.

Martínez, José Luis. "Una generación literaria. Taller". Galeras del Fondo de Cultura Económica, número titulado "Homenaje a Efraín Huerta", año 6, no. 56, febrero de 1992, p. 2

Montemayor, Carlos. Efraín Huerta. Colección Grandes Maestros Mexicanos, CREA / Terra Nova, 1985.

Ortega, Julio. Antología de la poesía hispanoamericana actual. Siglo XXI, 2009. 
Pacheco, José Emilio. "Esquema para un diccionario [abreviado] de la poesía de Efraín Huerta". Presentación del disco Efraín Huerta. Voz viva de México, Universidad Nacional Autónoma de México, 1968.

Paz, Octavio, Alí Chumacero et al., compiladores. Poesía en movimiento, tomo I, Secretaría de Educación Pública, 1985.

Paz, Octavio. "Efraín Huerta". La Gaceta del Fondo de Cultura Económica, no. 522, junio 2014, pp. 18-19. "Taller. Nueva generación Literaria". Galeras del Fondo de Cultura Económica, número titulado "Homenaje a Efraín Huerta", año 6, no. 56, febrero de 1992, p. 3.

Peirce, Charles Sanders. La ciencia de la semiótica. Ediciones Nueva Visíón, s.f.

Violli, Ugo. "Para una semiótica de la ciudad". Criterios, no. 61, 01 mayo 1914, pp. 1029-1046.

Zilberberg, Claude. Semiótica tensiva. Fondo Editorial / Universidad de Lima, 2006. 